\title{
The Power of Framing in Technology Governance: The Case of Biotechnologies
}





\title{
The Power of Framing in Technology Governance: The Case of Biotechnologies
}

\author{
Helge Torgersen, Alexander Bogner, Karen Kastenhofer \\ Institute of Technology Assessment, Austrian Academy of Sciences, Vienna
}

\section{Acknowledgements}

This research has been funded in part by the European Commission, DG Research under the $7^{\text {th }}$ Framework program, project 217815 "Sensitive Technologies and the European Public's Ethics" (STEPE), and by the Austrian Research Promotion Agency (FFG) under the program ELSAGEN, project 82381 "Towards a holistic conception of life? Epistemic presumptions and socio-cultural implications of systems biology" (THCL).

\section{Keywords}

Discursive frames, biotechnology, emerging technologies, technology controversies, technology governance, risk, ethics

\begin{abstract}
In past technology controversies, aspects such as risk or ethics have played a major role, apart from economic arguments. Public debates on agricultural biotechnology or biomedicine differed in the dominant aspect they addressed, respectively. This article specifies such aspects as discursive frames being tacit agreements over what is relevant and which arguments count. It investigates the role of frames in past debates and the relation between frames and issues relevant for technology governance such as policy advice, public participation and the political legitimation of decisions. For a newly emerging technology such as synthetic biology, the framing of a debate to come is often expected to follow patterns known from previous debates, and to influence governance in a foreseeable way. However, new frames might emerge that could change both the debate on and the governance of emerging technologies.
\end{abstract}




\section{Table of Contents}

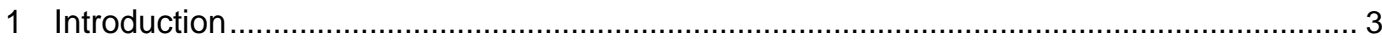

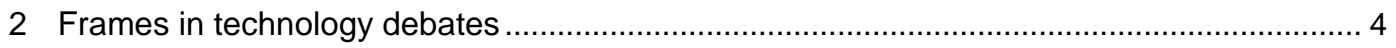

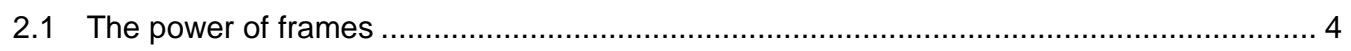

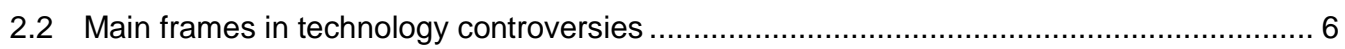

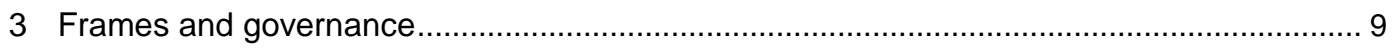

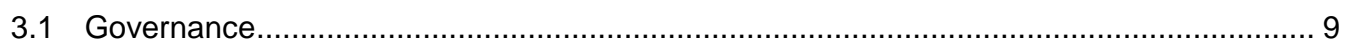

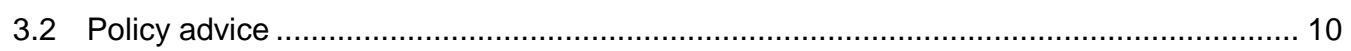

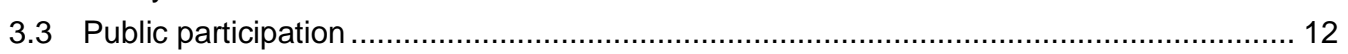

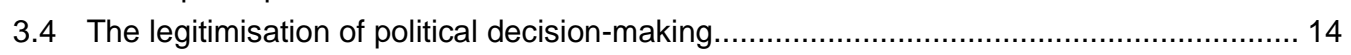

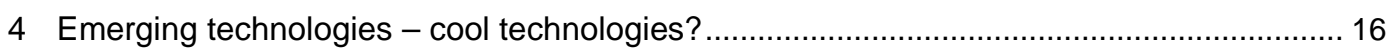

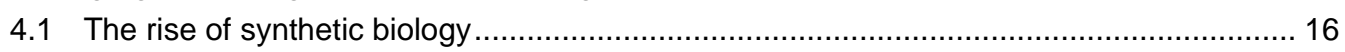

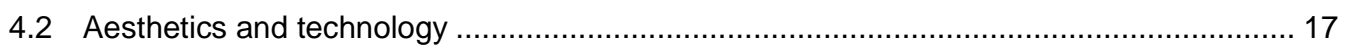

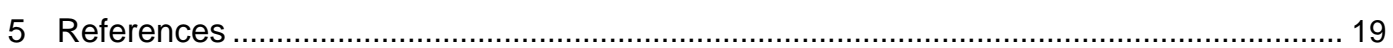

\section{MASTHEAD}

Media owner:

Austrian Academy of Sciences (ÖAW)

Legal person under public law (BGBI 569/1921 idF BGBI I 130/2003)

Dr. Ignaz Seipel-Platz 2, A-1010 Vienna

Editor:

Institute of Technology Assessment (ITA)

Strohgasse 45/5, A-1030 Vienna

www.oeaw.ac.at/ita

ITA manu:scripts appear at irregular intervals and publish working papers and talks from staff members as well as guests. ITA manu:scripts are exclusively made available to the public via the Internet portal "epub.oeaw":

http://epub.oeaw.ac.at/ita/ita-manuscript

ITA-manu:script No.: ITA-13-01 (October/2013)

ISSN-online: 1818-6556

http://epub.oeaw.ac.at/ita/ita-manuscript/ita_13_01.pdf

(C) 2013 ITA - All rights reserved 


\section{Introduction}

Novel technologies are an essential part of innovation regimes in modern societies. ${ }^{1}$ Hence, governments foster their development and implementation, often without the general public taking particular notice. With some technologies however, unforeseen controversies emerged, and biotechnology was one of them. ${ }^{2}$ In particular, applications in agriculture got contested (Bauer \& Gaskell 2002); in contrast, medical biotechnology elicited less conflict apart from single issues such as stem cell research (Mulkay 1997). ${ }^{3}$

Claims for a multitude of implications from these fields were raised, so they could have been debated in a variety of ways. However retrospectively, only a restricted number of issues and arguments were officially deemed relevant and acceptable in the debate while others got sidelined (Lindsey et al. 2001, Braun et al. 2010). Various actors strived to establish other issues and arguments as well, but at a certain point in time, a dominant perspective had manifested. Whether this was the 'right' one or others would have been more adequate remains open; nevertheless, the dominant way of holding the debate excluded other arguments, issues, policy options and, consequently, actors.

This raises several questions. Which frames would be possible in a technology controversy on a particular issue, and which have manifested in the past? What are the implications of a particular frame having acquired a dominant role? Which options for political action arise in technology controversies from a particular way of holding the debate? We think that the concept of frames may shed some light on these questions.

In this article we propose that there are different options for governance depending on the frame under which the technology is debated. In our understanding, frames provide the terms of communicative reference; they enable participants to argue on a common basis while restricting issues addressed, arguments brought up and actors admitted. Asking how a debate gets framed may therefore provide insights into the implications for technology governance. For example, a risk frame (having guided the debate over agricultural biotechnology) may lead to an entirely different choice of relevant issues and legitimate arguments than an ethics frame (having been dominant in the discourse on stem cell research).

The role of discursive frames in past technology debates may also shed light on possible debates over the governance of emerging technologies. For example, it is still unclear how the new field of synthetic biology will be debated in society - if it will be debated at all. Several analogies to past controversies suggest themselves, with particular framings and different consequences, respectively. Whether the frames from past controversies will be adequate for an emerging technology under the conditions of future debates remains open.

1 In the words of the European Commission (2009:151): "Creating, exploiting and commercialising new technologies has become essential in the global race for competitiveness. High-technology sectors are key drivers of economic growth, productivity and welfare, and are generally a source of high value added and well-paid employment."

2 Over the 1990s a considerable body of literature accumulated over science and technology controversies (i.e. Brante \& Elzinga 1990, Brante et al. 1993, Nelkin 1995). It triggered a plethora of case studies over very different fields such as BSE, GMOs, mobile phones, nuclear power and stem cell research.

3 Being still a research field, stem cell research is part of the larger technology of regenerative medicine. Since the term has established itself as a main bone of contention in technology debates it is referred to as a 'technology' here even if routine applications are not (yet) at hand. 
Before discussing the respective implications, chapter 2 will briefly introduce the concept of dominant frames such as 'risk', 'ethics' and 'the economy' and highlights their role in past debates on controversial fields of biotechnology. We will then address the current move away from top-down regulation towards technology governance and look at the relation between discursive frames and policy advice, public participation and the legitimisation of decision-making. The final part will discuss possible framings of synthetic biology as an example of an emerging technology as well as new perspectives opening up.

\section{Frames in technology debates}

For a better explanation of the discursive role of frames let us recall the conditions for holding a debate. Very generally, we have to focus on a particular object (in contrast to another) and talk about a specific aspect of this object. In other words, to communicate something we need a reference, and this is also necessary in a controversy. Here we quarrel, but to do so we also need a general (albeit often implicit) agreement over the topics considered relevant and the arguments held to be legitimate. In the following, we will call such an implicit agreement a frame.

\subsection{The power of frames}

A frame indicates which of the many possible topics in a debate over an issue is held to be relevant. It also determines which argument pertaining to the issue is considered legitimate. We may say that a frame gives significance to a thing as long as everybody involved in the debate agrees that the thing is significant, even if they disagree whether it is good or bad. Without a shared frame, however, there exists indifference rather than disagreement, as the German sociologist Georg Simmel (1904) pointed out, and a conflict could neither be initiated nor sustained. For example, a person who considers the chances and risks of a particular form of biotechnology irrelevant will not take a stance pro or contra. Only if opponents agree on the significance of this form of biotechnology, there is a reason for engagement. Thus, frames indicate what remains uncontested, namely the perceived relevance of the bone of contention. To carry out a controversy fuelled by normative differences, participants need to share a frame.

We are aware that in the literature, the term 'frame' has been conceptualised in different ways. Some authors understand frames as competing perspectives indicating normative and/or political positions in an actual controversy (Schön \& Rein 1994). ${ }^{4}$ Focusing on the particular normative content of a frame, this concept does not capture the above notion of a shared understanding of relevance necessary to carry out a debate. Rather, this aspect comes to the fore in the work of Erving Goffman (1974), who focuses on the interaction between individuals in everyday life and, therein, on the rules determining how meaning is assigned to a situation rather than to the content of the assignment. With this, Goffman tries to uncover implicit but commonly

4 This strongly normative component in the concept of the frame has been precisely formulated in Entman's (1993) definition of frame functions: frames define problems in a specific way, establish causal relations, anticipate evaluations, and provide guidance for action. 
shared patterns of structuring discourses. Such a perspective reveals that particular normative standpoints (the content) do not necessarily determine the discursive structure (the rules) of a debate. To make the distinction clearer: focusing on the content results in a frame concept such as Schön \& Rein (1994) developed, namely a classification of different normative positions. Analysing the implicit discursive rules, in contrast, results in a frame concept that emphasises patterns instructing participants how to perform a debate.

Here, we apply the latter understanding. Following Goffman (1974), therefore, we consider frames to be powerful organisation principles of individual perceptions and interpretations providing a common discursive basis for a debate. ${ }^{5}$ Accordingly, frames are principles that provide criteria for determining relevance and convey structures of orientation; they establish the relevant perspective that guides the discussion and determine the fundamental rules of the discourse. The function of a frame, in our understanding, is to create a shared discursive basis on which conflicts can be conducted.

This frame concept pertains to a level above that of concrete arguments, objectives and narratives appearing in the discourse. Regarding normative evaluations, frames (in this understanding) do not determine whether something is considered good or bad. More concrete: Frames provide an umbrella under which positive and negative arguments can be brought forward. Under a certain frame it is possible to argue both for and against the implementation of a technology. Frames are therefore not tantamount to a particular standpoint for or against an issue; rather, they determine whether an argument is legitimate.

To give an example: stem cell research ${ }^{6}$ was discussed mainly under an ethics frame (Evans 2002, Herrmann 2009). Under this frame, ethical arguments on the sanctity of life were brought forward to halt pertaining activities; at the same time, ethical arguments regarding individual autonomy and the saving of patients' lives were used to support it. The frame determined that arguments of a certain quality were relevant only, but it did not determine whether arguments were used for or against technology implementation.

From this perspective, the implicit power effects of frames become visible. On the one hand, frames direct and structure habits of seeing, thinking and acting; on the other hand, they determine controversies to the extent that adversaries must refer to an established frame in a constructive way. A dominant frame establishes powerful rules for the organisation of conflict communication; only certain issues and arguments become relevant and any issue of concern must fit the dominant frame - if not, it will be neglected.

The power of frames is reflected in the fact that actors need to constructively refer to them even if they personally do not share the perspective on the problem that is imposed by the frame. For biotechnology this means that as long as the issue is debated under an ethics frame politicians need to adopt ethical arguments even if they would prefer addressing the economic implications. The former German Chancellor Gerhard Schröder provided a nice example of such a re-formulation in an interview with a German quality newspaper: "According to my knowledge, biotechnology - apart from information and communication technology - will become one of the key technologies of this century. And the question which development perspective a country has is, after all, also of high socio-ethical relevance. Whether one can afford to forego certain economic opportunities of such a key technology - provided it is one - or not is a question that by no means is unethical." (Frankfurter Allgemeine Zeitung, 3.05.2001, own translation)

5 Goffman provided further insights regarding the relation between expertise and policy advice. For example Hilgartner (2000) refers to Goffman's metaphor of the theatre when analysing concrete political conflicts involving scientific advice in an US setting of adversarial hearings. This approach is not to the fore here.

6 Regarding its nature as a 'technology' see footnote 3. 
As a consequence, issues not compatible with a dominant frame may be suppressed for good; alternatively, they can reappear in different guises after having been adjusted to the dominant frame or survive without being really processed. For example, the cultivation of genetically modified crops has been debated mainly under a risk frame despite many economic implications such as the market dominance of multinational agrochemical companies (Levidow \& Boschert 2011). Although officially side-lined under the dominant risk frame, the issue survived only to reappear later and became a major issue not only for the technology opponents.

\subsection{Main frames in technology controversies}

In technology debates multiple frames are at work but it is often demanding to determine them. What individual members of the public discuss in a debate 'out there' in society is difficult to assess. Therefore, media analyses have often been applied to provide a mirror for communication events that are hard to access otherwise (Bauer 2000). Empirical media analyses have provided hints not only at the issues debated but also at the frames applied (Entman 1993). From these analyses, a limited set of three dominant main frames emerges: economic issues, ethics and risk. Other empirically determined frames can be subsumed under one of them (Dahinden 2006). ${ }^{7}$ In the following we will briefly address some main characteristics of the three dominant frames.

Economic issues: Following Habermas (1970), new technologies generally go along with explanations under an innovation rationale: in modern societies, technology is considered a major factor for generating economic prosperity and driving social change. Macro-economic hopes for social welfare motivate the massive support from governments for research activities. Micro-economic considerations are decisive for commercial companies for performing research and development - they expect economic benefits, otherwise they would not be engaged. Therefore, most arguments pertaining to technology implementation follow an economic frame, it may even be the default frame to be expected. Relevant arguments refer to individual or collective economic gain (such as an increase in GDP or the number of jobs), but also to the equitable distribution of benefits, a sustainable economy or to opportunities missed in case the technology is not implemented. From a basic rights' perspective, arguments often emphasise the freedom of enterprise or the right to maximise individual benefit.

The economic default frame goes mostly unmentioned as long as a technology has the reputation of providing growth and prosperity. For most application of biotechnology, this is the case. The economic frame is made explicit only if public scrutiny focuses on a particular form of technology such as stem cell research or agricultural biotechnology. Then this form gets challenged and eventually an ethics or risk frame becomes dominant in an ensuing technology controversy.

Ethics: Regarding medical applications, those related to the human embryo got under dispute in particular. With prenatal testing, genetic dispositions of the embryo can be detected, which could then lead to an abortion in case a genetic disease has been diagnosed. With stem cell research, cells from early human embryos are used in experiments invariably entailing their destruction. In both fields ethical concerns were raised: while prenatal testing could promote abortion and eventually lead to a segregating human life into worth and not worth living, stem

7 The basic frames Dahinden $(2006,210 \mathrm{ff})$ identified are conflict (equivalent to risk), profitability and progress (two aspects of the economic frame), moral concerns and personalisation, i.e. personal affectedness, which is not a discourse rule, however. 
cell usage rendered early human life subject to utility considerations as opposed to being a value in itself. These ethical concerns contributed to promoting a large interest in bioethics and gave rise to a wealth of literature (for an encyclopaedic approach: Reich 1995). Ethics is therefore the dominant frame in the debate over these forms of medical biotechnology. Although a hypothetical treatment with stem cells elicits concerns over associated risks for the patient (such as failure or severe side effects like cancer), the main debate issue was and largely is whether stem cell research should be considered ethically acceptable or not. Often, reference is made to basic ethical principles such as dignity, autonomy, integrity or vulnerability (Rendtorf 2002). Emphasising one of these principles over another, however, may lead to a different conclusion with regard to ethical acceptability, respectively. Thus it is possible to argue in favour of or against stem cell research under the same ethical frame.

Risk: Risk has been one of the main issues in the debate over biotechnology (or genetic engineering) from its very beginning (Berg et al. 1981). One of the most disputed fields was agricultural biotechnology, often referred to as genetically modified (or GM) crops and food (for an overview of the arguments and their policy implications see Levidow \& Carr 2010). Here, foreign genes are artificially introduced to give crop plants certain properties like herbicide resistance, insect tolerance or the ability to produce different substances to increase the productivity or alter the product quality. Opponents claim that the procedure and the foreign genes could lead to unanticipated ecological or health risks; proponents cannot see significantly increased risks beyond those the original crop plant conveys. Although genetically modified plants may also raise ethical and economic questions such as food security and global distributional justice (EGE 2008), environmental and health risks have long been maintained as the dominating perspective both in the media and the policy arena (Gottweis 1998).

The basic difference of true and false in risk conflicts points to their character as knowledge conflicts. Accordingly, scientific methods and criteria can and should determine risk, for example whether a transgenic plant can have detrimental effects on human health and the environment and how likely this is. Thus, at stake was mostly whether there is a risk and how big it might be. The technical dimensions of the analysis and the experimental details as well as potential conflict interests of those doing the experiments often became subject to disputes (Wynne 2007a). The result was uncertainty, differently interpreted: opponents tended to consider uncertain risks inacceptable; proponents preferred to ask whether they mattered when measured against conventional alternatives.

For example with genetically modified insect-tolerant crops like maize (that kill certain pest insects without farmers having to apply chemical pesticides), a risk of negative effects on human health from eating such maize has been claimed (recently: Séralini et al. 2012, rejected officially by the European Food Safety Authority ${ }^{8}$ ), questioning reassurances that there is no detectable risk. ${ }^{9}$ Opponents, with a view to uncertainty from diverging expert opinions, keep demanding a halt to the technology. ${ }^{10}$ Proponents often point at known risks from pesticides in conventional agriculture that would be omitted with $\mathrm{GM}$ crops, ${ }^{11}$ rendering highly uncertain health risks from GMOs irrelevant. Thus, under a risk frame both pro and contra arguments may be raised.

8 http://www.efsa.europa.eu/en/press/news/121004.htm (retrieved 05-12-2013).

${ }^{9}$ EC-funded projects demonstrated that risk is negligible (for example http://www.gmsafoodproject.eu/SciPublications.aspx? section=3278IdType=327, retrieved 05-12-2013).

10 Séralini is engaged in a civil society group opposing agricultural biotechnology. They used his article for campaigning (http://www.criigen.org/SiteEn/index.php?option=com_content\&task=view6id=3668ltemid=130, retrieved 05-12-2013). The article has been retracted late in 2013.

11 Several agricultural scientific institutions primarily in the USA entertain websites mostly intended for farmers explaining the advantages and some disadvantages of GMOs in agriculture (for example http://12.000.scripts.mit.edu/mission2014/genetically-modified-crops, retrieved 05-12-2013). 
Taken together, a single dominant frame generally determines the structure of legitimate arguments in biotechnology controversies although different issues may come up. Frames differ in what is at stake, and consequently determine how to deal with it. Risks from technological intervention into natural processes basically relate to hazards for human health or the environment, so risk assessments describe, in scientific terms, possible hazards and their likelihood (Jaeger et al. 2001). The relevant knowledge is scientific and debates over risk claims preferably address scientific arguments. The relevant questions, accordingly, are: what is the case, is a statement true or false, which knowledge is more reliable and which party can command better data to support their stance.

With ethics as the dominant frame, in contrast, natural scientific data are merely inputs to a deliberation process. The ethics frame demands answers to entirely different questions: what can be defended ethically? Which value arguments should be supported? Who can mobilise moral hegemony over the stance of others? The relevant type of knowledge, on ethical arguments, is clearly different from that in risk debates.

This is put against an economic frame that usually prevails as long as there is no controversy. Arguments pertain to economic benefits, their distribution and consequences. The relevant form of knowledge is economic, derived from (quantitative) assessments, intended to answer questions about whether an endeavour leads to individual or collective gains or losses, who benefits and what the contribution to innovation and growth is.

Table 1 shows main differences in a generalised way.

Table 1: The risk and the ethics frame

\begin{tabular}{|c|c|c|c|}
\hline Frame & Risk & Ethics & Economy \\
\hline Subject of dispute & Correct knowledge & Moral imperative & Socio-economic benefit \\
\hline Key questions & $\begin{array}{l}\text { How big is the risk of an } \\
\text { intervention into natural } \\
\text { processes? Are there } \\
\text { negative consequences? }\end{array}$ & $\begin{array}{l}\text { Where are the limits to } \\
\text { science and technology? } \\
\text { What kind of knowledge } \\
\text { do we want? }\end{array}$ & $\begin{array}{l}\text { Does it contribute to } \\
\text { innovation and growth? } \\
\text { What would be lost if not } \\
\text { implemented? } \\
\text { Who benefits? }\end{array}$ \\
\hline Basic difference & True - false & Good - bad & Useful - futile \\
\hline Examples & $\begin{array}{l}\text { Nuclear energy, mobile } \\
\text { phones, GM crops, } \\
\text { nanotechnology }\end{array}$ & $\begin{array}{l}\text { Cloning, genetic } \\
\text { diagnosis, stem cell } \\
\text { research, human } \\
\text { enhancement }\end{array}$ & $\begin{array}{l}\text { 'Default' frame for } \\
\text { most technology } \\
\text { implementations }\end{array}$ \\
\hline
\end{tabular}

Which frame emerges as the dominant one also depends on the references made to previous cases of technology debates, in other words to the rhetorical comparator. Although not entirely open for choice, in many cases there are a number of possible comparators; accordingly, the frames may differ. For example, GM crops were looked upon as agricultural varieties or as agro-chemicals; stem cells were held akin to medical devices or links were drawn to embryo experimentation. Thus, frames are results of past discourses (for the biotechnological field of xenotransplantation see Michael \& Brown 2004). Their respective dominance depends on the relative power of the actors involved, their preferred perspectives and the references they make to previous apparently similar cases and their political contexts (Torgersen \& Hampel 2011). 


\section{Frames and governance}

As already mentioned, the economic frame can be considered the default frame for technology implementation in the absence of a controversy. The other way round, risk and ethics are frames that challenge the economic frame. This constitutes a problem for governance. In the following chapter we will look closer at the link between frames and governance. Our focus will be on risk and ethics in their role as dominant and challenging frames, since the economic frame is to be held the 'normal case'. We will only look at frame-specific challenges to governance, in contrast to general political problems with new technologies that may also be dealt with under an economic frame. This means that we will emphasise possibilities for governance under the frames of risk or ethics on different levels: what are the specific conditions for governance? What does this imply for policy advice? What are the perspectives for public participation and the opportunities for the legitimisation of decisions?

\subsection{Governance}

A main aim of regulatory oversight over technologies is to contain negative effects. Risks to human health or the environment tend to be mitigated by 'rational action' giving rise to technical regulation or tort law (Jaeger et al. 2001). Ethical boundaries, in contrast, often got addressed in the form of subjective decisions of conscience or by morally argued laws; they constitute a political problem 'beyond left or right' (Giddens 1994). Usually decisions have to be taken under extreme time pressure: by the time a political deliberation would perhaps have come to a conclusion in one question, the technology will have further developed and thrown up entirely different questions.

Especially with new technologies therefore, top-down regulation has shown its limits. For example in risk regulation, due to a lack in scientific knowledge it is often difficult to determine whether a risk exists. Mandatory state induced measures to mitigate uncertain risks are often contested, while alternative measures might be more timely and flexible. Ethical objections rarely trigger state action from the outset even if ethics committees consider them relevant. Hence, under both a risk and an ethics frame, forms of dealing with a contested issue are preferred that omit formal regulation (for synthetic biology see Presidential Commission, 2010).

This, among other factors, is why governance in the sense of opening up towards broader participation has become an alternative. This understanding of governance has been coined for non-hierarchical, network-based, co-operative forms of governing. ${ }^{12}$ Although fuzzy, it indicates that the idea of a stringent state control is being challenged: rather than governments steering top-down, networks of coordination predominate that aim at gaining higher rationality and better legitimation for decision-making (Mayntz 2003, Kooiman 2003). The collective coordination of action often takes place in a multi-level system rather than being determined by a central state (Bache 2004, Zürn 2010). Among the advantages claimed are an increase in democratic legitimisation and a greater steering capacity. In contrast to inflexible regulation lagging behind technological development, governance is often considered more appropriate to deal with powerful but intricate technologies. Not least, governance emphasises the voluntary involvement

12 For a short account of the development of the term see Mayntz (2003). 
of relevant actors in shaping measures like guidelines or best practice agreements, which may enhance their commitment by assigning responsibility.

In biotechnology governance, new stakeholder arrangements with their focus on deliberation and co-operation (Rosenau 1995, Héritier 2002) brought a variety of new actors and stakeholders into the picture such as environmental groups, consumer organisations, patient initiatives, expert panels, ethics committees, think tanks for policy advice etc. The number of actors, instruments, locations and levels of negotiations multiplied. Together with public debate increasing in intensity, this made political decision-making more complex. Consequently, new instruments were created such as various participatory or public dialogue procedures (Bora \& Hausendorf 2010).

With a move from top-down regulation to governance, the boundary between public or stakeholder debate and regulatory decision-making tends to blur. This suggests that frames dominant in the debate acquire greater influence on decisions taken and measures chosen. For example, the dominant frame usually establishes who is entitled to speak (and thus to influence decision-making) and in which form a decision must be legitimised. Consequently, frames also might become important for advice-giving institutions and their performance. Therefore we will discuss three related aspects how frames might influence governance: with respect to policy advice (3.2), public participation (3.3) and decision legitimisation (3.4).

\subsection{Policy advice}

Under a dominant risk frame, science is in the driving seat and the prerogative in risk governance goes to scientific and technical experts with a particular knowledge who usually constitute technical boards (Jaeger et al. 2001: 217). ${ }^{13}$ To be considered relevant, objections to technology implementation have to be framed as relating to risk (to human health or the environment) and be put before the technical experts' panel. The risk frame would stipulate that any other argument should not be considered legitimate as it pertained to irrelevant aspects. Policy advice then takes the form of a research-based identification of facts to be measured according to scientific reliability, validity and objectivity.

For example, the marketing of a novel genetically modified food has to be officially permitted in Europe (EC 2001). After a scientific risk assessment has been performed, the national competent authority decides on the application after having been advised by a scientific committee. If different member states do not agree on the decision, they have to formulate the reasons in scientific terms, pointing at faults in the assessment or facts that have newly emerged. Then a scientific body of the EU, the European Food Safety Authority (EFSA) ${ }^{14}$, checks the evidence provided. Since numerous quarrels over the adequacy of the assessments arose between member countries, the European institutions have taken a number of governance measures to accommodate or refuse the protest (Levidow 2009, Baram \& Bourrier 2011). Here, the dispute took the form of a knowledge conflict: whose evidence is better, who can show the more convincing experiments, whose interpretations are logically more consistent?

\footnotetext{
13 We are aware that keeping up a risk frame against challenges has normative implications. This has been highlighted by scholars in ethics and sociology or STS time and again (for example Wynne 2007a, Stirling 2008, Levidow \& Boschert 2011) However, this article focuses on the structural rules of a debate and not on the normative implications.

14 http://www.efsa.europa.eu/
} 
In contrast, under an ethics frame the objectivity of an argument is not the most important category. Other than with ethics committees overviewing clinical therapies and research, in policy advice ethics expertise is intended to be balanced rather than objective. This is so even if reared by experts, and even on a European level (such as with the European Group on Ethics ${ }^{15}$ ). By definition, every argument pertains to a value judgement and there are many legitimate positions to each problem. In fact, the selection of the members of national ethics councils already aims at mirroring the plurality of possible views; they usually are multi-disciplinary and often include a wide variety of experts and stakeholders. ${ }^{16}$ Apart from ethicists, people holding different forms of expertise and world-views may legitimately have a say and contribute their opinion (for example on the legitimacy of embryonic stem cell research). Hence, dissent is considered the normal case and therefore implicitly deemed legitimate (Galloux et al. 2002, Bogner 2010). ${ }^{17}$ The ethical experts' advice takes the form of a deliberation-based balanced value judgement ideally reflecting pluralism in society.

Table 2 compares main differences between policy advice under a risk and an ethics frame.

Table 2: Policy advice and frames

\begin{tabular}{lll}
\hline & Risk Governance & Ethics Governance \\
\hline Relevant expertise & Natural sciences & $\begin{array}{l}\text { Natural and social sciences, } \\
\text { religious authorities, humanities; } \\
\text { lay knowledge }\end{array}$ \\
\hline Form of institutionalisation & $\begin{array}{l}\text { Risk research, } \\
\text { risk assessment panels } \\
\text { and agencies }\end{array}$ & Ethics committees and councils \\
\hline Production of relevant knowledge through & Research & Deliberation \\
\hline Expectation from expertise & Objectivity & Balance \\
\hline
\end{tabular}

15 The mandate of the EGE stipulates in article 3: "Members are nominated ad personam. Members serve in a personal capacity and are asked to advise the Commission independently from any outside influence. The EGE shall be independent, pluralist and multidisciplinary."

(http://ec.europa.eu/bepa/european-group-ethics/welcome/mandate-2011-2016/index_en.htm, retrieved 05-12-2013).

16 Technical committees on risk may also comprise of members from different technical and scientific disciplines; however, in contrast to ethics committees, they rarely span a range from natural to social sciences and humanities.

17 An exception, at first sight, is the UK Nuffield Council on Bioethics (http://www.nuffieldbioethics.org/, retrieved 05-12-2013), who aims at unanimous positions in their reports. However, the composition of the panels for a particular question is reported to usually mirror the quest for non-deviating views from beforehand. 


\subsection{Public participation}

Not the least as a result of recalcitrant controversies there were frequent calls for public participation if new technologies were to be implemented. These calls were taken up in numerous participatory exercises of different formats (Rowe \& Frewer 2005, Lengwiler 2008). Multiple forms of participatory procedures emerged to bring into dialogue experts, policy makers, stakeholders and the public on various subjects. Apart from institutionalised participation through statutory hearings of those involved, a methodological canon for participatory technology assessment (PTA) developed, aiming at involving persons not involved in assessment procedures so far (Joss \& Bellucci 2002). Such participation experiments often take the form of third-party funded projects designed by actors from the Science and Technology Studies (STS) field.

Observers from this field coined the term of a 'deliberative' (Kearnes 2009) or 'democratic turn' (Hagendijk \& Irwin 2006) in technology policy. Participatory procedures, it was argued, could help politicising technology issues exclusively discussed in closed circles otherwise (Callon et al. 2011). Involving users and communities affected was seen as a step towards democratising the innovation process (von Hippel 2005). Scholars considered deliberation processes over normative aspects of innovation and technology a fundamental precondition for responsible policy making on science and technology (Felt and Wynne 2007). The turn towards 'participatory governance' also led to attempts at involving the public 'upstream' in the early phases of technological innovation (Wilsdon \& Willis 2004).

Demands for participation have now also entered the political mainstream, where they meet a forceful innovation agenda. Involving the public is said to address societal concerns pro-actively and thereby render technology governance more democratic and robust (European Commission 2001). Particularly in European policy narratives, 'responsible research and innovation' (von Schomberg 2012) has become an important concept aiming at public engagement with science and technology.

However, with an increasing number of practical experiences at hand, the scholarly enthusiasm for public participation somewhat faded. The resonance of project-shaped participation events in the political arena had been very low in general. Ambivalent results gave rise to more critical appraisals, and a number of reasons why expectations failed were identified (for example Delgado et al. 2011). We think that since frames also have implications for public participation, a perspective taking into account the dominant frame in a debate may be revealing.

Participatory procedures were often initiated to bring alternative views into technology conflicts deadlocked under a risk frame. However, in risk debates rational expert opinion ('sound science') is considered relevant, while lay people constitutively are at a disadvantage due to their lack of specialised scientific knowledge. For risk governance, lay participation is therefore structurally incompatible with the dominant risk frame and often restricted or considered less relevant. When participatory attempts are launched in the context of risk controversies, "the full realisation of a kind of participative governance is enormously difficult: it requires a shift of mentality, broad changes in professional and institutional practices, and the design and implementation of new instruments and procedures" (De Marchi 2003: 171).

Disagreement therefore provoked other means of articulation - in practice, risk controversies often mobilised 'uninvited' participation (Wynne 2007b: 107): many lay persons protest against, for example, a GM crop release, irrespective whether experts see a risk or not. Such protests often become politically relevant as they forcefully interfere with technology implementation as the political default program. This relevance acquired a dynamic of its own, since the controversy over GMOs got interpreted as a menacing example, if not a blueprint that an innovation 
agenda lacking efforts at 'going public' is doomed to fail. An early public debate was frequently advocated to prevent such a failure (from different reasons, see EASAC 2010, Presidential Commission 2010, Barben et al. 2008).

Issues with a strong emphasis on ethics (such as stem cell research), in contrast, rarely lead to mass demonstrations. They appear to be more suitable for lay deliberation just because their assessment demands value judgements - which everybody might be entitled to (after having been made familiar with the technicalities). ${ }^{18}$ In terms of governance, public participation is an obvious method to deal with these issues (Joss \& Bellucci 2002). However, few members of the public are really interested in participating because applications are to be expected in a distant future only and nobody is presently affected. Therefore, procedures often serve to mobilise participation in events that deal with an issue that is rarely linked to an actual public controversy, to a pursuit of political participation actively brought forward or to individual concerns (Bogner 2012).

A good example for a large participatory procedure under an ethics frame was the project on the implications of brain research called 'Meeting Minds', organised in 2006 on behalf of the EU Commission in 18 member states (Boussaguet \& Dehousse 2009). The problem here seemed to be to attract enough participants to the events to arrive at conclusions that would not only mirror the experts' positions. In contrast, the 2003 UK large-scale experimental project GM Nation? on the question of whether or not to use GM crops - which is mostly considered a risk issue - was much more attractive among the public. However, it revealed other problems: analyses suggested, for example, that it mattered who got involved, which arguments were considered relevant and how the debate was held (Reynolds \& Szerszynski 2006, Levidow 2009, Irwin 2006, Horlick-Jones et al. 2007). The implications for technology governance remained, in total, equally unclear.

Table 3 summarises differences in public participation under risk or ethics governance.

Table 3: Public participation and frames

\begin{tabular}{lll}
\hline & Risk Governance & Ethics Governance \\
\hline Form of articulation & Protest & Project-shaped participation \\
\hline Mobilisation & Autonomous [bottom-up] & By participation experts [top-down] \\
\hline Frame compatibility & Weak & Strong \\
\hline Potential impact & Considerable & Weak \\
\hline
\end{tabular}

18 Baronesse Helena Kennedy, the former chairperson of the Human Genetics Commission, said on the occasion of a House of Lords meeting on the question of whether Great-Britain needs a national ethics council: "I am unhappy about subcontracting ethics to a group of ethicists. (...) we are all ethicists." (House of Lords, 28.01.2008, Human Fertilisation and Embryology Bill, Vol. 698, cols 489f.). 


\subsection{The legitimisation of political decision-making}

The perspective on different frames also shows that governance under a risk frame demands different forms of legitimation for pertinent decisions compared to governance under a perspective of ethics. This has to do with the terms of reference and the preferred forms of expertise, respectively.

From a juridical point of view, arguments under a risk frame refer to the basic right of bodily integrity or of an intact environment not jeopardising health. This usually is uncontroversial provided the existence of a pertaining risk can be established scientifically. Therefore, risk assessment and related exercises are highly salient in the political decision-making. Politicians rarely dare to neglect a scientific-technical panel's assessment because they cannot claim knowing better. For example in 2009, when the then German Minister of Agriculture prohibited the release of a genetically modified maize variety she explicitly stated that she had taken "a decision founded by expertise and not a political one" (FAZ, 18.04.2009, own translation). Although the sceptical majority among the public had admittedly impressed her, she exclusively pointed at new scientific results: accordingly, two experimental reports had proved beyond doubt that 'gene maize' may be detrimental to the environment.

Under an ethics frame, in contrast, the main source of legitimisation is the individual conscience of those providing the opinion, be they experts, politicians or laypersons. The normative basis under an ethics frame is the freedom of belief and the free expression of opinion. Often, reference is made to broad ethical principles such as dignity or autonomy, but they need to be interpreted for the particular case. Consequently, various rights might be inferred, but not self-evidently so; rather, participants in a debate have to argue that a particular right is at stake.

The result of an ethical deliberation such as that in an ethics committee is usually less tightly linked to the decision-making process and therefore less binding (Bogner \& Menz 2010). Ethical experts' advice may be easily overturned because a decision on the issue is considered subject to the individuals' (and the individual politicians') conscience and value preferences. This also applies for political decisions: if Parliament votes on questions relevant to bioethics, faction whip usually is lifted, and those who do not approve of such a lift get criticised from within the faction. For example with the deliberations for a new UK embryo act, the then Prime Minister Gordon Brown initially rejected demands for a free vote for Government Ministers according to their individual conscience, pointing at the eminent importance for the research place. After severe protests, he was forced to put parts of the law at disposition for a free vote (BBC News, 25.03.2008).

Nik Brown and Mike Michael (2002) argued that under an ethics frame a shift from authority to authenticity occurs. Authority with its system of control, evidence and risk objectification is no longer functional as it creates trust through transparency in an objectified way only. However, claims for transparency remain contested as transparency "needs to be performed persuasively if it is to be accepted" (Brown \& Michael 2002: 260). Taking the example of xenotransplantation, they showed that the shift to the performance level entails an upgrading of authenticity: When trust in experts and numbers fails, politicians need to credibly demonstrate that they have heard all relevant voices, wracked their brains and wrestled hard with their conscience. This shift from authority and objectified risk to authenticity and participation is at the bottom of what may be called ethics governance.

Table 4 shows main differences for the legitimisation of decisions under different frames. 
Table 4: Legitimisation of decisions under different frames

\begin{tabular}{lll}
\hline & Risk Governance & Ethics Governance \\
\hline Reference & Expert knowledge & Conscience \\
\hline Basic right & $\begin{array}{l}\text { Right of bodily integrity, } \\
\text { right of intact environment }\end{array}$ & $\begin{array}{l}\text { Freedom of belief, various rights } \\
\text { subject to deliberation }\end{array}$ \\
\hline Role of expertise & Determining facts & Advising on alternatives \\
\hline Political decision-making & Bound by external expertise & Subject to individual conscience \\
\hline
\end{tabular}

Finally, it is not only possible to debate technology implementation under a risk or ethics frame; rather, arguments about benefit and its distribution may also be raised under an economic frame, and numerous points of dissent may ensue. A return of the economic frame can often be observed later in a debate. For example, the mandatory labelling of genetically modified food in the EU can be understood as the result of such a return of the economic frame. The measure was not argued as mitigating risk but builds on the freedom of product choice linked to benefit considerations. ${ }^{19}$ Another example is the argument that pre-natal testing would not be cost-efficient in reducing genetic diseases (viewed critically from a STS perspective: Wieser 2006).

Taken together, we have identified some implications for governance of discussing an issue under different frames. During a technology controversy, risk and ethics frames tend to attack a dominant economic frame mostly in the guise of technology criticism. However, technologies do not always get opposed under a risk or ethics frame; neither does an economic frame invariably support the introduction of a technology. Anyway, different frames entail different consequences for governance, respectively, and measures have to address entirely different policy areas or stakeholders. This may cause problems when frame dominance eventually shifts again.

19 Officially, risks from GM food products would have been detected and such products excluded under the procedures necessary for the marketing approval, but "The EU recognises the consumers' right to information and labelling as a tool for making an informed choice."

(http://ec.europa.eu/food/food/biotechnology/gmfood/labelling_en.htm, retrieved 05-12-2013).

The "Right to Know Genetically Engineered Food Act" proposal in California got rejected but shows that this issue has reached the US public and policy arena as well

(http://www.guardian.co.uk/commentisfree/2012/jun/13/california-gm-referendum-change-america-food, retrieved 05-12-2013), acclaimed by GM-critical NGOs such as GeneWatch. 


\section{Emerging technologies - cool technologies?}

Discursive framing as described above has played an important role in debating and governing technologies in the past. It is also relevant for today's (or tomorrow's) debates on emerging technologies (Kastenhofer 2009). Emerging technologies by definition are still in their youths, their identity is visionary and their specific outline is still abstract and ambiguous. They often do not represent technologies in a traditional sense but refer to new approaches spanning a wide range of single technologies and research fields, rendering their definition problematic (Nordmann 2011). Although stakeholders often promote their development highlighting the potential applicability, they are still mostly confined to basic research. So far, they have resulted in only few applications the broader public have access to.

\subsection{The rise of synthetic biology}

All this applies to synthetic biology in particular. Although no generally accepted definition exists, synthetic biology is mostly referred to as the design and construction of new biological parts, devices, and systems, and the re-design of existing natural biological systems for useful purposes. Synthetic biology aims at introducing true engineering principles into biology. ${ }^{20}$ Based on recent insights from genomics and other fields, metabolic pathways or organisms are constructed from standardised parts and devices (Benner \& Sismour 2005). This engineering attitude mostly shapes the image and the self-understanding of relevant actors.

So far, a significant public debate has been absent. Nevertheless, public engagement and dialogue is considered essential (EGE 2009; Presidential Commission 2010), not the least because arguments and approaches based on science only are considered insufficient to contain future public unease (Zhang et al. 2011). But what will these debates be on, if they arise? Which frames will be dominant? What problems will ensue for governance subject to the dominant frames, respectively?

For emerging technologies, the development is still open. Therefore it is not easy to realistically determine concrete risks and benefits, let alone societal perceptions and ethical problems. Yet to stimulate a public debate 'upstream' it is necessary to identify possibly contentious topics. Few civil society organisations have dealt with the synthetic biology; basically only one, the ETC Group, have issued an early critical report (ETC Group 2007). De Vriend (2006) as well as Balmer \& Martin (2008) provided more scholarly accounts of probable issues to discuss. Official reports followed, repeatedly addressing a canonical set of anticipated problems (e.g. EGE 2009, Presidential Committee 2010, IRGC 2010, EASAC 2010). Schmidt et al. (2009) in a 'priority paper' comprehensively identified main points for discussion such as: i) potential bioterrorism and accidents; ii) the implications of 'creating life'; iii) the question of intellectual property rights and the ownership of the technology. Looking upon these issues under the perspective of frames suggests that the first two groups belong to frames known from the biotechnology debate, namely risk and ethics. The third group, pointing at equity as a contingency of innovation, can be subsumed under an economic frame. The listing of potential points for debate thus tacitly implies that the frames synthetic biology will be discussed under will be similar to those in past biotechnology debates.

20 See the definition on the Synthetic Biology Community's website (http://syntheticbiology.org/, retrieved 21-01-2012). 
This may be an effect of emulation. In the absence of concrete knowledge, direct experiences and established framings, past controversies with other technologies shape the image of a new one together with current visions (Nordmann \& Schwarz 2009, for nanotechnology: Selin 2007). STS scholars, politicians and civil society organisations have drawn speculative analogies to other technologies, in particular agricultural biotechnology: synthetic biology has been said to be at risk of meeting a similar public rejection. ${ }^{21}$ This would suggest that in the future, a risk frame would be dominant. The danger of bioterror or accidents (the latter claimed mostly in Europe, the former in the US, mirroring previous transatlantic differences, Schmidt 2006) would support such an assumption. The metaphor of 'creating life', in contrast, clearly addresses an ethics frame. In contrast to expert assumptions, press analyses (Pauwels \& Ifrim 2008, Cserer \& Seiringer 2009) showed that so far, the issue of 'creating life' appeared less frequent than issues linked to risk and benefit (Hellsten \& Nerlich 2011). ${ }^{22}$

At the same time, promoters have drawn speculative analogies to past breakthroughs in biotechnology as well as to science fiction narratives to envision the innovative and powerful character of synthetic biology. The benefits emphasised pertained mostly to economic opportunities; however, they also carried an image of societal usefulness beyond unspecific contributions to growth and competitiveness. Applications promoted were, for example, new ways of producing pharmaceuticals desired in the Third World and renewable energy from abundant resources (Endy 2005).

If we look at them under the perspective of different frames, respectively, the list of potential problems resembles those discussed with past technologies: risks to human health and the environment, ethical problems from manipulating an amalgam of matter and life, and economic implications related to intellectual property rights or access to the technology. They implicitly suggest known governance strategies and measures, such as technical risk mitigation, ethical deliberation and patent or open source solutions. In addition, the looming danger of public rejection many experts see should be addressed, accordingly, by eliciting an early public debate and a variety of outreach activities (EASAC 2010).

\subsection{Aesthetics and technology}

This said, there is a difference to previous debates over biotechnology, though. Among others, the issue of intellectual property rights, i.e. patents versus open source, is related to a different comparator. Not only biotechnology but also information technology serves as the relevant benchmark here.

This is not accidentally so. Researchers in synthetic biology often consider their field to be an information technology as well, using DNA base sequences instead of electronic bits and bytes. Analogies refer to elements of the technologies such as information hierarchies or organisation principles (Adrianantoandro et al. 2006) as well as to the growth in capacity (of data storage or DNA sequencing and synthesis, respectively) and the decrease in cost seemingly following a Moore's law. The closest link, though, is established through the scientists themselves - many protagonists had formerly been into information technology and had changed the field in favour

21 This fear also occurred with nanotechnology, without a public controversy really existing. A. Rip identified a 'nanophobia-phobia' among experts expecting controversies about nanotechnology due to 'folk theories' of alleged risk perception among the public (Rip 2006).

22 Even the heavy coverage of the person of Craig Venter, who had claimed to have achieved creating life, did not change the picture (Cserer \& Seiringer 2009). 
of synthetic biology. ${ }^{23}$ They bring with them their professional world-view, including their engineering thinking in building blocks, devices and systems, and apply it to genes, cells and organisms (Endy 2005, Knight 2005, Heinemann \& Panke 2006, MacDonald et al. 2011). Supported by the comparison to information technology silently but constantly accompanying the discourse, emulating a similar image conveys entirely different perspectives than those that were dominant in previous debates on biotechnology.

Information technology has greatly contributed to many intellectuals' as well as the general publics' acquaintance to technology as an essential and highly esteemed part of life. Users develop bonds of trust to their computers and rely on the possibilities they offer for accessing the world. A playful relation has developed to technology as a useful tool, but also as a toy. Information technology has developed into a synonym for the most powerful, pervasive and at the same time 'cool' thing imaginable, with technical gadgets galore. It not only is economically pervasive but has become a lifestyle determinant (Negroponte 1995, Rainie \& Wellman 2012).

With this comparator, technology debates are held under an entirely different perspective. For example, the world-wide iGEM competition ${ }^{24}$ for young students carries a decisively egalitarian attitude and is designed to elicit enthusiasm. It has become a major public relation agent not unlike competitions in computer engineering. A number of other demonstrative similarities to the IT sector like Do-it-Yourself communities (including lay 'garage shops' and 'biohackers' ${ }^{25}$ ), art exhibitions or film festivals ${ }^{26}$ have contributed to solidify a more both reflexive and cool image of synthetic biology not only among biotechnology students but potentially for society at large.

The perspective that may be seen emerging here is decisively different from the frames having been dominant in the debates on biotechnology so far. It is not so much related to risk or to ethics, and neither to classical economic implications like growth or the distribution of benefits. All these more tangible categories of past debates get addressed now and then, especially when it comes to grappling with the 'societal implications' (which constitutes a mandatory task for participants in the iGEM competition, for example). Rather, they form an integral part of a more aesthetic dealing with issues around synthetic biology in the work of experts, artists and amateurs - critically embracing rather than uncritically accepting the technology as a contribution to innovation irrespective of its properties, or rejecting it as a symbol of a misguided modernity.

This overarching perspective is of a different, more affective quality. Essentially, it is related to lifestyle, to a playful attitude towards the technology, to its role as a potentially useful toy or artistic medium, in short, to aesthetic rather than ethical, risk or economic categories. In a positive way, it elicits enthusiasm, and indifference or even disgust in a negative one. It is less dependent on expertise than on empathy, and the political impact is doubtful and hardly calculable. Consequently, the governance of such a technology would have to seek new ways beyond confining itself to risk mitigation, ethical deliberation or economic growth and equity issues.

23 For example, Randy Rettberg, the founder of the iGEM competition, is one of the fathers of the Internet.

24 http://igem.org/Main_Page (retrieved 05-12-2013).

25 http://www.biohackers.la/ (retrieved 05-12-2013).

${ }^{26}$ For example the biofiction exhibition and film festival

(http://www.bio-fiction.com/pdf/biofiction_programm_web.pdf, retrieved 05-12-2013). 
A legitimate question would be whether the discursive development regarding synthetic biology might follow a pattern with broader implications. Can we see a new frame emerging, originating from information technology and being emulated in synthetic biology and possibly other fields as well? Such a new frame may eventually modify future debates on other forms of technology beyond biotechnology, too. It is even tempting to speculate that the case of information technology has changed the perspective for good, and that a more general shift in the societal debate of technologies may be at hand.

\section{References}

Adrianantoandro, Ernesto, Subhayu Basu, David K. Karig and Ron Weiss 2006. Synthetic biology: new engineering rules for an emerging discipline. Molecular Systems Biology 2:2006.0028.

Bache, Ian (ed) 2004. Multi-level Governance. Oxford: Oxford University Press.

Balmer, Andrew and Paul Martin 2008. Synthetic Biology. Social and Ethical Challenges. Report for the Working Group of the Bioscience for Society Strategy Panel of the BBSRC. University of Nottingham.

Baram, Michael and Mathilde Bourrier 2011 (eds). Governing Risk in GM Agriculture. Cambridge: Cambridge University Press.

Barben, Daniel, Erik Fisher, Cynthia Selin and David H. Guston 2008. Anticipatory Governance of Nanotechnology: Foresight, Engagement, and Integration. In Handbook of Science and Technology Studies, Third Edition. E. J. Hackett et al. (eds). Cambridge, Mass.: MIT Press, 979-1000.

Bauer, Martin W. 2000. Classical content analysis: a review. In Qualitative Researching with Text, Image and Sound. M.W. Bauer and G. Gaskell (eds) 131-151. London: Sage

Bauer, Martin W. and George Gaskell (eds) 2002. Biotechnology: The Making of a Global Controversy. Cambridge, UK: Cambridge University Press.

Benner, Steven A. and A. Michael Sismour 2005. Synthetic biology. Nature Reviews Genetics $6: 533-543$.

Berg, Paul, David Baltimore, Sydney Brenner, Richard O. Roblin III, and Maxine F. Singer 1981. Summary Statement of the Asilomar Conference on Recombinant DNA Molecules. Proceedings of the National Academy of Science 72(6):1981-1984.

Bogner, Alexander 2010. Let's disagree! Talking Ethics in Technology Controversies. Science, Technology \& Innovation Studies 6(2): 183-201.

Bogner, Alexander 2012. The Paradox of Participation Experiments. Science, Technology \& Human Values 37(5): 506-527.

Bogner, Alexander and Wolfgang Menz 2010. How Politics Deals with Expert Dissent: The Case of Ethics Councils. In: Science, Technology, \& Human Values 35 (6): 888-914.

Bora, Alfons and Heiko Hausendorf (eds) 2010. Democratic Transgressions of Law: Governing Technology through Public Participation. Leiden/Boston: Brill.

Boussaguet, Laurie and Renaud Dehousse 2009. Too big to fly? A review of the first EU citizens' conferences. Science and Public Policy 36(10): 777-789. 
Brante, Thomas and Aant Elzinga 1990. Towards a theory of scientific controversies. Science Studies 3(2): 33-46.

Brante, Thomas, Steve Fuller and William Lynch (eds) 1993. Controversial science: From content to contention. Albany, NY: State University of New York Press.

Braun, Kathrin, Svea Luise Herrmann, Sabine Könninger and Alfred Moore 2010. Ethical Reflection Must Always be Measured. Science, Technology \& Human Values 35(6): 839-864.

Brown, Nik and Mike Michael 2002. From authority to authenticity: the changing governance of biotechnology. Health, Risk \& Society 4(3): 259-272.

Callon, Michel, Pierre Lascoumes and Yannick Barthe 2011. Acting in an Uncertain World. An Essay on Technical Democracy. Cambridge: The MIT Press.

Cserer, Amélie and Brigitte Seiringer 2009. Pictures of Synthetic Biology: A reflective discussion of the representation of Synthetic Biology (SB) in the German-language media and by SB experts. Systems \& Synthetic Biology 3:27-35.

Dahinden, Urs 2006. Framing. Eine integrative Theorie der Massenkommunikation. Konstanz: UVK.

De Marchi, Bruna 2003. Public participation and risk governance. Science and Public Policy 30(3), 171-176.

Delgado, Ana, Kamilla Lein Kjølberg and Fern Wickson 2011. Public engagement coming of age: From theory to practice in STS encounters with nanotechnology. Public Understanding of Science 20(6):826-845.

deVriend, Huib 2006. Constructing Life. Early social reflections on the emerging field of SB. Working Document 9. The Hague: Rathenau Instituut.

EASAC (European Academies Science Advisory Council) 2010. Realising European potential in synthetic biology: scientific opportunities and good governance.

http://www.easac.eu/home/reports-and-statements/detail-view/article//synthetic-bi-1.html (retrieved 05-12-2013).

EC 2001. European Parliament and Council Directive 2001/18/EC of 12 March on the deliberate release into the environment of genetically modified organisms and repealing Council Directive 90/220EEC. Official Journal of the European Communities L106, 17 April: 1-38.

European Commission 2009. Science, technology and innovation in Europe. Luxembourg: Office for Official Publications of the European Communities.

EGE 2008. Ethics of modern developments in agricultural technologies. Opinion No. 24. Brussels: The European Group on Ethics in Science and New Technologies to the European Commission.

EGE 2009. Ethics of synthetic biology. Opinion No 25. Brussels: The European Group on Ethics in Science and New Technologies to the European Commission.

Endy, Drew 2005. Foundations for engineering biology. Nature 438(7067): 449-453.

Entman, Robert M. 1993. Framing: Toward Clarification of a Fractured Paradigm. Journal of Communication 43(4), 51-58.

ETC Group 2007. Extreme Genetic Engineering: An Introduction to Synthetic Biology. Ottawa: ETC Group.

European Commission 2001. European Governance. A White Paper. Brussels: Commission of the European Communities.

Evans, John H. 2002. Playing God? Human Genetic Engineering and the Rationalization of Public Bioethical Debate. Chicago: University of Chicago Press. 
Felt, Ulrike and Brian Wynne 2007. Taking European Knowledge Society Seriously. Report of the Expert Group on Science and Governance to the Science, Economy and Society Directorate. Brussels: European Commission, Directorate General for Research.

Galloux, Jean-Christophe, Arne Thing Mortensen, Suzanne Cheveigné, Agnes Allandsdottir, Aigli Chatjouli, and George Sakellaris (2002): The institutions of bioethics. In Biotechnology. The Making of a Global Controversy. M. W. Bauer and G. Gaskell (eds). Cambridge: Cambridge University Press, 129-148.

Giddens Anthony 1994. Beyond Left and Right: The Future of Radical Politics. Palo Alto, CA: Stanford University Press.

Goffman, Erving 1974. Frame Analysis: An Essay on the Organization of Experience. London: Harper and Row.

Gottweis, Herbert 1998. Governing Molecules: The Duscursive Politics of Genetic Engineering in Europe and the United States. Cambridge, MA: MIT Press.

Habermas, Jürgen 1970. Technology and Science as "Ideology". In Toward a Rational Society: Student Protest, Science, and Politics. J. Shapiro (transl.). Boston: Beacon Press.

Hagendijk, Rob and Alan Irwin 2006. Public Deliberation and Governance: Engaging with Science and Technology in Contemporary Europe. Minerva 44: 167-184.

Heinemann, Matthias and Sven Panke 2006. Synthetic biology-putting engineering into biology. Bioinformatics 22: 2790-2799.

Hellsten, lina and Brigitte Nerlich 2011. Synthetic biology: Building the language for a new science brick by metaphorical brick. New Genetics and Society. 30(4): 375-397.

Herrmann, Svea L. 2009. Policy Debates on Reprogenetics. The Problematisation of New Research in Great Britain and Germany. Frankfurt/New York: Campus.

Héritier, Adrienne (ed) 2002. Common Goods: Reinventing European and International Governance. Lanham, MD: Rowman \& Littlefield.

Hilgartner, Stephen 2000. Science on Stage - Expert Advice as Public Drama. Stanford, CA: Stanford University Press.

Horlick-Jones, Tom, John Walls, Gene Rowe, Nick Pidgeon, Wouter Poortinga, Graham Murdock and Tim O'Riordan 2007. The GM Debate. Risk, politics and public engagement. London and New York, Routledge.

IRGC 2010. Guidelines for the Appropriate Risk Governance of Synthetic Biology. Geneva: International Risk Governance Council.

Irwin, Alan 2006. The Politics of Talk: Coming to Terms with the 'New' Scientific Governance. Social Studies of Science 63(2): 299-320.

Jaeger, Carlo C., Ortwin Renn, Eugene A. Rosa and Thomas Webler 2001. Risk, Uncertainty and Rational Action. London: Earthscan.

Joss, Simon and Sergio Bellucci 2002. Participatory Technology Assessment - European Perspectives. Centre for the Study of Democracy (CSD). London: University of Westminster

Kastenhofer, Karen 2009. Debating the risks and ethics of emerging technosciences. Innovation, The European Journal of Social Science Research 22(1): 77-103.

Kearnes, Matthew 2009. The Time of Science: Deliberation and the 'New Governance' of Nanotechnology. In Governing Future Technologies - Nanotechnology and the Rise of an Assessment Regime. Sociology of the Sciences Yearbook Vol. 27. M. Kaiser, M. Kurath, S. Maasen and Ch. Rehmann-Sutter (eds). Dordrecht: Springer, 279-301. 
Knight, Thomas F. 2005. Engineering novel life. Molecular Systems Biology 1:2005.0020.

Kooiman, Jan 2003. Governing as Governance. London: Sage.

Lengwiler, Martin 2008. Participatory Approaches in Science and Technology. Historical Origins and Current Practices in Critical Perspective. Science, Technology \& Human Values 33(2), 186-200.

Levidow, Les 2009. Democratizing agri-biotechnology? European public participation in agbiotech assessment. Comparative Sociology 8(4): 541-564.

Levidow, Les and Susan Carr 2010. GM Food on Trial. Testing European Democracy. London: Routledge.

Levidow, Les and Karin Boschert 2011. Segregating GM Crops: Why a Contentious 'Risk' Issue in Europe? Science as Culture 20(2): 255-279.

Lindsey, Nicola, Mercy W. Kamara, Erling Jelsoe and Arne Thing Mortensen 2001. Changing Frames: the Emerging of Ethics in European Policy on Biotechnology. Politeia 17: 80-93.

MacDonald, James T., Chris Barnes, Richard I. Kitney, Paul S. Freemont and Guy-Bart v. Stan 2011. Computational design approaches and tools for synthetic biology. Integrative Biology 2:97-108.

Mayntz, Renate 2003. New Challenges to Governance Theory. In New Challenges to Governance Theory. H. P. Bang (ed). Manchester: Manchester University Press, 27-40.

Michael, Mike and Nik Brown 2004. The meat of the matter: grasping and judging xenotransplantation. Public Understanding of Science 13(4): 379-397.

Mulkay, Michael 1997. The Embryo Research Debate. Cambridge, UK: Cambridge University Press.

Negroponte, Nicholas 1995. Being Digital. New York: Alfred A. Knopf.

Nelkin, Dorothy 1995. Science Controversies: The Dynamics of Public Disputes in the United States. In Handbook of Science and Technology Studies. S. Jasanoff et al. (eds). Thousand Oaks: Sage, 444-456.

Nordmann, Alfred 2011. The Age of Technoscience. In Science Transformed? Debating Claims of Epochal Breaks. A. Nordmann, H. Radder and G. Schiemann (eds). Pittsburgh: Pittsburgh University Press, 19-30.

Nordmann, Alfred and Astrid Schwarz 2009. Lure of the "Yes": The Seductive Power of Technoscience. In Governing Future Technologies. Nanotechnology and the Rise of an Assessment Regime. M. Kaiser et al. (eds). New York: Springer, 255-277.

Pauwels, Eleonore and Ioan Ifrim 2008. Trends in American and European Press Coverage of Synthetic Biology. Tracking the last five years of coverage. Washington: Woodrow Wilson international Centre for Scholars. http://www.synbioproject.org/library/publications/archive/why_scientists_should_care/ (retrieved 05-12-2013).

Presidential Commission 2010. New Directions. The Ethics of Synthetic Biology and Emerging Technologies. Washington DC: Presidential Commission for the Study of Bioethical Issues.

Rainie, Lee and Barry Wellman 2012. Networked: The New Social Operating System. Cambridge, MA: MIT Press.

Reich, Warren T. (ed.) 1995. The Encyclopedia of Bioethics, $5^{\text {th }}$ edition. London: Macmillan.

Reynolds, Larry and Bronislaw Szerszynski 2006. Representing GM Nation. PATH conference proceedings, 4-7 June 2006, Edinburgh, UK. Aberdeen: Macaulay Institute. http://www.macaulay.ac.uk/PATHconference/outputs/PATH_abstract_1.2.3.pdf (retrieved 05-12-2013). 
Rendtorff, Jacob D. 2002. Basic ethical principles in European bioethics and biolaw: Autonomy, dignity, integrity and vulnerability - Towards a foundation of bioethics and biolaw. Medicine, Health Care and Philosophy 5(3): 235-244.

Rip, Arie 2006. Folk Theories of Nanotechnologies. Science as Culture 15(4): 349-365.

Rosenau, James N. 1995. Governance in the Twenty-First Century. Global Governance 1:13-43.

Rowe, Gene and Lynn J. Frewer 2005. A Typology of Public Engagement Mechanisms. Science, Technology \& Human Values 30(2): 251-290.

Schmidt, Markus 2006. Public will fear biological accidents, not just attacks. Nature 441(7097):1048.

Schmidt, Markus, Agomoni Ganguli-Mitra, Helge Torgersen, Alexander Kelle, Anna Deplazes and Nikola Biller-Andorno 2009. A priority paper for the societal and ethical aspects of synthetic biology. Systems and Synthetic Biology 3(1-4): 3-7.

Schön, Donald A. und Martin Rein 1994. Frame Reflection: Toward the Resolution of Intractable Policy Controversies. New York: Basic Books.

Selin, Cynthia 2007. Expectations and the Emergence of Nanotechnology. Science, Technology \& Human Values 32(2): 196-220.

Séralini, Gilles-Eric, E. Clair, R. Mesnage, S. Gressa, N. Defargea, M. Malatestab, D. Hennequinc, J. Spiroux de Vendômois 2012. Long term toxicity of a Roundup herbicide and a Rounduptolerant genetically modified maize. Food and Chemical Toxicology 50(11): 4221-4231.

Simmel, Georg 1904. The Sociology of Conflict. American Journal of Sociology 9: 490-525.

Stirling, Andy 2008. "Opening Up" and "Closing Down": Power, Participation, and Pluralism in the Social Appraisal of Technology. Science, Technology \& Human Values 33(2): 262-94.

Torgersen, Helge and Jürgen Hampel 2011. Calling controversy: assessing synthetic biology's conflict potential. Public Understanding of Science 21(2):134-148.

von Hippel, Eric 2005. Democratizing Innovation. Cambridge: The MIT Press.

von Schomberg, René 2012. Prospects for technology assessment in a framework of responsible research and innovation. In M. Dusseldorp and R. Beercroft (eds), Technikfolgen abschätzen lehren. Wiesbaden: VS, 39-61.

Wieser, Bernhard 2006. Inescapable Decisions. Implications of New Developments in Prenatal Testing. Science, Technology \& Innovation Studies 2(1): 41-56.

Wilsdon, James and Rebecca Willis 2004. See-through Science: Why public engagement needs to move upstream. London: Demos.

Wynne Brian 2007a. Risky Delusions: Misunderstanding Science and Misperforming Publics in the GE Crops Issue. In Genetically Engineered Crops: Interim Policies, Uncertain Legislation. I. E. P. Taylor (ed). Philadelphia: Haworth Press, 341-372.

Wynne, Brian 2007b. Public Participation in Science and Technology: Performing and Obscuring a Political-Conceptual Category Mistake. East Asian Science, Technology and Society: an International Journal 1(1): 99-110.

Zhang, Joy, Claire Marris and Nikolas Rose 2011. The Transnational Governance Synthetic Biology. Scientific uncertainty, cross-borderness and the 'art' of governance. BIOS Working Papers. London: London School of Economics and Political Science.

Zürn, Michael 2010. Global Governance as Multi-Level Governance. In Handbook on Multilevel Governance. M. Zürn et al. (eds). Cheltenham: Edward Elgar Publishers, 80-99. 


\section{Previously published manu:scripts}

ITA-01-01 Gunther Tichy, Walter PeissI (12/2001): Beeinträchtigung der Privatsphäre in der Informationsgesellschaft. $<$ www.oeaw.ac.at/ita/pdf/ita_01_01.pdf>

ITA-01-02 Georg Aichholzer (12/2001): Delphi Austria: An Example of Tailoring Foresight to the Needs of a Small Country. <www.oeaw.ac.at/ita/pdf/ita_01_02.pdf>

ITA-01-03 Helge Torgersen, Jürgen Hampel (12/2001): The Gate-Resonance Model: The Interface of Policy, Media and the Public in Technology Conflicts. <www.oeaw.ac.at/ita/pdf/ita_01_03.pdf>

ITA-02-01 Georg Aichholzer (1/2002): Das ExpertInnen-Delphi: Methodische Grundlagen und Anwendungsfeld "Technology Foresight". <www.oeaw.ac.at/ita/pdf/ita_02_01.pdf>

ITA-02-02 Walter Peissl (1/2002): Surveillance and Security - A Dodgy Relationship. $<$ www.oeaw.ac.at/ita/pdf/ita_02_02.pdf>

ITA-02-03 Gunther Tichy (2/2002): Informationsgesellschaft und flexiblere Arbeitsmärkte. $<$ www.oeaw.ac.at/ita/pdf/ita_02_03.pdf>

ITA-02-04 Andreas Diekmann (6/2002): Diagnose von Fehlerquellen und methodische Qualität in der sozialwissenschaftlichen Forschung. <www.oeaw.ac.at/ita/pdf/ita_02_04.pdf>

ITA-02-05 Gunther Tichy (10/2002): Over-optimism Among Experts in Assessment and Foresight. <www.oeaw.ac.at/ita/pdf/ita_02_05.pdf>

ITA-02-06 Hilmar Westholm (12/2002): Mit eDemocracy zu deliberativer Politik? Zur Praxis und Anschlussfähigkeit eines neuen Mediums. <www.oeaw.ac.at/ita/pdf/ita_02_06.pdf>

ITA-03-01 Jörg Flecker und Sabine Kirschenhofer (01/2003): IT verleiht Flügel? Aktuelle Tendenzen der räumlichen Verlagerung von Arbeit. <www.oeaw.ac.at/ita/pdf/ita_03_01.pdf>

ITA-03-02 Gunther Tichy (11/2003): Die Risikogesellschaft - Ein vernachlässigtes Konzept in der europäischen Stagnationsdiskussion. <www.oeaw.ac.at/ita/pdf/ita_03_02.pdf>

ITA-03-03 Michael Nentwich (11/2003): Neue Kommunikationstechnologien und Wissenschaft - Veränderungspotentiale und Handlungsoptionen auf dem Weg zur Cyber-Wissenschaft. <www.oeaw.ac.at/ita/pdf/ita_03_03.pdf>

ITA-04-01 Gerd Schienstock (1/2004): Finnland auf dem Weg zur Wissensökonomie - Von Pfadabhängigkeit zu Pfadentwicklung. <www.oeaw.ac.at/ita/pdf/ita_04_01.pdf>

ITA-04-02 Gunther Tichy (6/2004): Technikfolgen-Abschätzung: Entscheidungshilfe in einer komplexen Welt. $<w w w . o e a w . a c . a t /$ ita/pdf/ita_04_02.pdf>

ITA-04-03 Johannes M. Bauer (11/2004): Governing the Networks of the Information Society - Prospects and limits of policy in a complex technical system. <www.oeaw.ac.at/ita/pdf/ita_04_03.pdf>

ITA-04-04 Ronald Leenes (12/2004): Local e-Government in the Netherlands: From Ambitious Policy Goals to Harsh Reality. <www.oeaw.ac.at/ita/pdf/ita_04_04.pdf>

ITA-05-01 Andreas Krisch (1/2005): Die Veröffentlichung des Privaten - Mit intelligenten Etiketten vom grundsätzlichen Schutz der Privatsphäre zum Selbstschutz-Prinzip. <www.oeaw.ac.at/ita/pdf/ita_05_01.pdf>

ITA-05-02 Petra Grabner (12/2005): Ein Subsidiaritätstest - Die Errichtung gentechnikfreier Regionen in Österreich zwischen Anspruch und Wirklichkeit. <http://epub.oeaw.ac.at/ita/ita-manuscript/ita_05_02.pdf>

ITA-05-03 Eva Buchinger (12/2005): Innovationspolitik aus systemtheoretischer Sicht - Ein zyklisches Modell der politischen Steuerung technologischer Innovation. <www.oeaw.ac.at/ita/pdf/ita_05_03.pdf>

ITA-06-01 Michael Latzer (6/2006): Medien- und Telekommunikationspolitik: Unordnung durch Konvergenz - Ordnung durch Mediamatikpolitik. <epub.oeaw.ac.at/ita/ita-manuscript/ita_06_01.pdf>

ITA-06-02 Natascha Just, Michael Latzer, Florian Saurwein (9/2006): Communications Governance: Entscheidungshilfe für die Wahl des Regulierungsarrangements am Beispiel Spam. <epub.oeaw.ac.at/ita/ita-manuscript/ita_06_02.pdf>

ITA-06-03 Veronika Gaube, Helmut Haberl (10/2006): Sozial-ökologische Konzepte, Modelle und Indikatoren nachhaltiger Entwicklung: Trends im Ressourcenverbrauch in Österreich. <epub.oeaw.ac.at/ita/ita-manuscript/ita_06_03.pdf>

ITA-06-04 Maximilian Fochler, Annina Müller (11/2006): Vom Defizit zum Dialog? Zum Verhältnis von Wissenschaft und Öffentlichkeit in der europäischen und österreichischen Forschungspolitik. <epub.oeaw.ac.at/ita/ita-manuscript/ita_06_04.pdf>

ITA-06-05 Holger Floeting (11/2006): Sicherheitstechnologien und neue urbane Sicherheitsregimes. <epub.oeaw.ac.at/ita/ita-manuscript/ita_06_05.pdf>

ITA-06-06 Armin Spök (12/2006): From Farming to „Pharming” - Risks and Policy Challenges of Third Generation GM Crops. <epub.oeaw.ac.at/ita/ita-manuscript/ita_06_06.pdf>

ITA-07-01 Volker Stelzer, Christine Rösch, Konrad Raab (3/2007): Ein integratives Konzept zur Messung von Nachhaltigkeit - das Beispiel Energiegewinnung aus Grünland. <epub.oeaw.ac.at/ita/ita-manuscript/ita_07_01.pdf>

ITA-07-02 Elisabeth Katzlinger (3/2007): Big Brother beim Lernen: Privatsphäre und Datenschutz in Lernplattformen. <epub.oeaw.ac.at/ita/ita-manuscript/ita_07_02.pdf>

ITA-07-03 Astrid Engel, Martina Erlemann (4/2007): Kartierte Risikokonflikte als Instrument reflexiver Wissenspolitik <epub.oeaw.ac.at/ita/ita-manuscript/ita_07_03.pdf>

ITA-07-04 Peter Parycek (5/2007): Gläserne Bürger - transparenter Staat? Risiken und Reformpotenziale des öffentlichen Sektors in der Wissensgesellschaft. <epub.oeaw.ac.at/ita/ita-manuscript/ita_07_04.pdf>

ITA-07-05 Helge Torgersen (7/2007): Sicherheitsansprüche an neue Technologien - das Beispiel Nanotechnologie. <epub.oeaw.ac.at/ita/ita-manuscript/ita_07_05.pdf>

ITA-07-06 Karen Kastenhofer (9/2007): Zwischen „schwacher“ und „starker“ Interdisziplinarität. Die Notwendigkeit der Balance epistemischer Kulturen in der Sicherheitsforschung zu neuen Technologien. <epub.oeaw.ac.at/ita/ita-manuscript/ita_07_06.pdf> 
ITA-07-07 Ralf Lindner, Michael Friedewald (9/2007): Gesellschaftliche Herausforderungen durch „intelligente Umgebungen. Dunkle Szenarien als TA-Werkzeug. <epub.oeaw.ac.at/ita/ita-manuscript/ita_07_07.pdf>

ITA-07-08 Alfons Bora (11/2007): Die disziplinären Grundlagen der Wissenschaft. <epub.oeaw.ac.at/ita/ita-manuscript/ita_07_08.pdf>

ITA-08-01 Alexander Degelsegger (5/2008): „Frames“ in sozialwissenschaftlichen Theorieansätzen. Ein Vergleich aus der Perspektive der Technikforschung. <epub.oeaw.ac.at/ita/ita-manuscript/ita_08_01.pdf>

ITA-08-02 Jens Hoff (11/2008): Can The Internet Swing The Vote? Results from a study of the 2007 Danish parliamentary election. <epub.oeaw.ac.at/ita/ita-manuscript/ita_08_02.pdf>

ITA-09-01 Georg Aichholzer, Doris Allhutter (2/2009): e-Participation in Austria: Trends and Public Policies. <epub.oeaw.ac.at/ita/ita-manuscript/ita_09_01.pdf>

ITA-09-02 Michael Nentwich (11/2009): Cyberscience 2.0 oder 1.2? Das Web 2.0 und die Wissenschaft. <epub.oeaw.ac.at/ita/ita-manuscript/ita_09_02.pdf>

ITA-09-03 Hilmar Westholm (12/2009): Wandel der Formen politischer Partizipation und der Beitrag des Internet. Schlussfolgerungen aus Bevölkerungsbefragungen in Deutschland. <epub.oeaw.ac.at/ita/ita-manuscript/ita_09_03.pdf>

ITA-10-01 Iris Eisenberger (12/2010): Kleine Teile, große Wirkung? Nanotechnologieregulierung in der Europäischen Union. <epub.oeaw.ac.at/ita/ita-manuscript/ita_10_01.pdf>

ITA-10-02 Alexander Degelsegger and Helge Torgersen (12/2010): Instructions for being unhappy with PTA. The impact on PTA of Austrian technology policy experts' conceptualisation of the public. <epub.oeaw.ac.at/ita/ita-manuscript/ita_10_02.pdf>

ITA-10-03 Ernest Braun (12/2010): The Changing Role of Technology in Society. <epub.oeaw.ac.at/ita/ita-manuscript/ita_10_03.pdf>

ITA-10-04 Fritz Betz (12/2010): E-Partizipation und die Grenzen der Diskursethik. <epub.oeaw.ac.at/ita/ita-manuscript/ita_10_04.pdf>

ITA-11-01 Peter Parycek, Judith Schoßböck (1/2011): Transparency for Common Good. Offener Zugang zu Information im Kontext gesellschaftlicher und strategischer Spannungsfelder. <epub.oeaw.ac.at/ita/ita-manuscript/ita_11_01.pdf>

ITA-11-02 Georg Aichholzer und Doris Allhutter (6/2011): Online forms of political participation and their impact on democracy. <epub.oeaw.ac.at/ita/ita-manuscript/ita_11_02.pdf>

ITA-11-03 Mahshid Sotoudeh, Walter Peissl, Niklas Gudowsky, Anders Jacobi (12/2011): Long-term planning for sustainable development. CIVISTI method for futures studies with strong participative elements. <epub.oeaw.ac.at/ita/ita-manuscript/ita_11_03.pdf>

ITA-12-01 Xiao Ming (1/2012): e-Participation in Government Decision-Making in China. Reflections on the Experience of Guangdong Province. <epub.oeaw.ac.at/ita/ita-manuscript/ita_12_01.pdf>

ITA-12-02 Stephan Bröchler, Georg Aichholzer, Petra Schaper-Rinkel (Hrsg.) (9/2012): Theorie und Praxis von Technology Governance. <epub.oeaw.ac.at/ita/ita-manuscript/ita_12_02_Sondernummer.pdf>

ITA-12-03 Iris Eisenberger (10/2012): EU-Verhaltenskodex Nanotechnologie: Rechtsstaatliche und demokratische Aspekte. <epub.oeaw.ac.at/ita/ita-manuscript/ita_12_03.pdf>

ITA-12-04 Julia Haslinger, Christiane Hauser, Peter Hocke, Ulrich Fiedeler (10/2012): Ein Teilerfolg der Nanowissenschaften? Eine Inhaltsanalyse zur Nanoberichterstattung in repräsentativen Medien Österreichs, Deutschlands und der Schweiz. <epub.oeaw.ac.at/ita/ita-manuscript/ita_12_04.pdf>

ITA-13-01 Helge Torgersen, Alexander Bogner, Karen Kastenhofer (10/2013): The Power of Framing in Technology Governance: The Case of Biotechnologies. <epub.oeaw.ac.at/ita/ita-manuscript/ita_13_01.pdf> 